\title{
In vitro susceptibility of rainbow trout fin cells to viral haemorrhagic septicaemia virus
}

\author{
A. Estepa, D. Frías, J. M. Coll* \\ INIA Sanidad Animal, CISA, Valdeolmos, E-28130 Madrid, Spain
}

\begin{abstract}
Cells isolated from rainbow trout fins Oncorhynchus mykiss, Walbaum were propagated and subcultured as fibroblast-like. Viral haemorrhagic septicaemia virus (VHSV) replicated in the cultured fin cells as demonstrated by fin cell lysis, positive immunofluorescence with polyclonal antiVHSV, and increase in titre as measured by either infection of fish cell lines or by sandwich ELISA with anti-VHSV monoclonal antibodies. The possible use of these fin cell cultures as VHSV-antigen presenting cells for immunological studies is briefly discussed.
\end{abstract}

\section{INTRODUCTION}

In rainbow trout Oncorhynchus mykiss, Walbaum, the isolation of viral haemorrhagic septicaemia virus (VHSV) (Chilmonczyk \& Oui 1988), has been related to their virus presence in trout lymphoid organs after in vivo infection. Furthermore, VHSV in vitro replication has been demonstrated in different trout primary or subcultured tissues, such as head kidney pronephros leucocytes (Estepa \& Coll 1991a), mitogen-induced leucocyte colonies (Estepa \& Coll 1991b), macrophages (Estepa et al. 1992) and pronephros stromal cultures (Diago et al. unpubl.).

This work demonstrates the in vitro VHSV replication on a non-lymphoid trout tissue, the fin cell population adapted to grow in vitro. A primary trout cell culture that could be established without killing the donor and be infected with VHSV after several rounds of in vitro multiplication, such as the one described in this work, would facilitate the study of the hypothetical VHSV-antigen presentation mechanisms to their autologous lymphocytes.

\section{MATERIAL AND METHODS}

Fin cells from rainbow trout. Trout $(20 \mathrm{~g}$ body weight) were purchased from a commercial farm. Several annual tests have indicated this farm to be free of

\footnotetext{
- Addressee for correspondence
}

infectious pancreatic necrosis and/or VHS (Uña, Cuenca, Spain). The trout were maintained individually in $30 \mathrm{l}$ aquaria equipped with biological filter units. Water recirculation was about $30 \mathrm{ml} \mathrm{min}^{-1}$. The trout were anaesthesized with MS.222 and cooled to $4{ }^{\circ} \mathrm{C}$ before one of the ventral fins was cut and removed from the trout. After the surgical operation the wounds of the trout were disinfected with ethanol and the trout were put back into their closed system aquaria with the addition of $250 \mu \mathrm{g}$ fungizone $\mathrm{ml}^{-1}$ and $50 \mu \mathrm{g}$ gentamicin $\mathrm{ml}^{-1}$. Under these conditions trout survival was $100 \%$. The fin was cut into pieces in a Petri-dish, and incubated in $0.5 \%$ Trypsin-10 mM EDTA in RPMI1640 for 5 to $10 \mathrm{~min}$. Clumps of cells were dissociated by passing the suspension through a Pasteur pipette, and the cell suspension was centrifuged at $1000 \times g$ for 10 min, resuspended in cold cell culture medium and cultured at $14^{\circ} \mathrm{C}$ in $25 \mathrm{~cm}^{2}$ cell culture flasks.

The cell culture media (Flow Lab, Ayrshire, Scotland) was RPMI-1640 (Dutch modification) with $2 \mathrm{mM} \mathrm{L}$ glutamine, $1 \mathrm{mM}$ sodium pyruvate, $1.2 \mu \mathrm{g} \mathrm{ml}^{-1}$ fungizone, $50 \mu \mathrm{g} \mathrm{ml}^{-1}$ gentamicin, $20 \mathrm{mM}$ Hepes, $50 \mu \mathrm{M}$ mercaptoethanol, $10 \%$ pretested fetal calf serum and $0.5 \%$ pooled rainbow trout serum as described by Estepa \& Coll (1992).

Viral haemorrhagic septicaemia virus (VHSV). The strain of virus used was VHSV 07.71 (gift from Dr de Kinkelin, INRA, Jouy en Josas, France) isolated from rainbow trout. The virus was cultured in epithelioma papillosum cyprini (EPC) cells, and added to the fin cultures as supernatant from infected cell monolayers after their complete cytopathic effect. 
To titrate the virus by cell culture after fin infection, the supernatant from lysed fin cells was centrifuged at $10000 \times g$ for $10 \mathrm{~min}$ and cultured at 5 -fold dilutions in EPC cell monolayers by the TCID $_{50}$ method (Basurco \& Coll 1989). Parallel cultures to which the viruses were added immediately before processing were used as controls so that both cultures could be exposed to the same possible diluting errors.

Immunofluorescence. Immunofluorescence of SHVinfected cells (about $1 \mathrm{TCID}_{50}$ per 100 fin cells) was carried out after fixing the cultures with ethanol $3 \mathrm{~d}$ after infection, using international reference polyvalent anti-VHSV antisera (gift from Dr de Kinkelin). The method was used as described by Basurco (1990).

Enzyme linked immunosorbent assay (ELISA). Centrifuged supernatant from virus lysed fin cell cultures was also examined for the presence of VHSV by the 2 monoclonal antibody-based ELISA sandwich as previously described (Sanz \& Coll 1992). The supernatants of the infected cultures were tested by 2 -fold dilutions in duplicates against titrated supernatants from VHSV lysed EPC cell cultures.
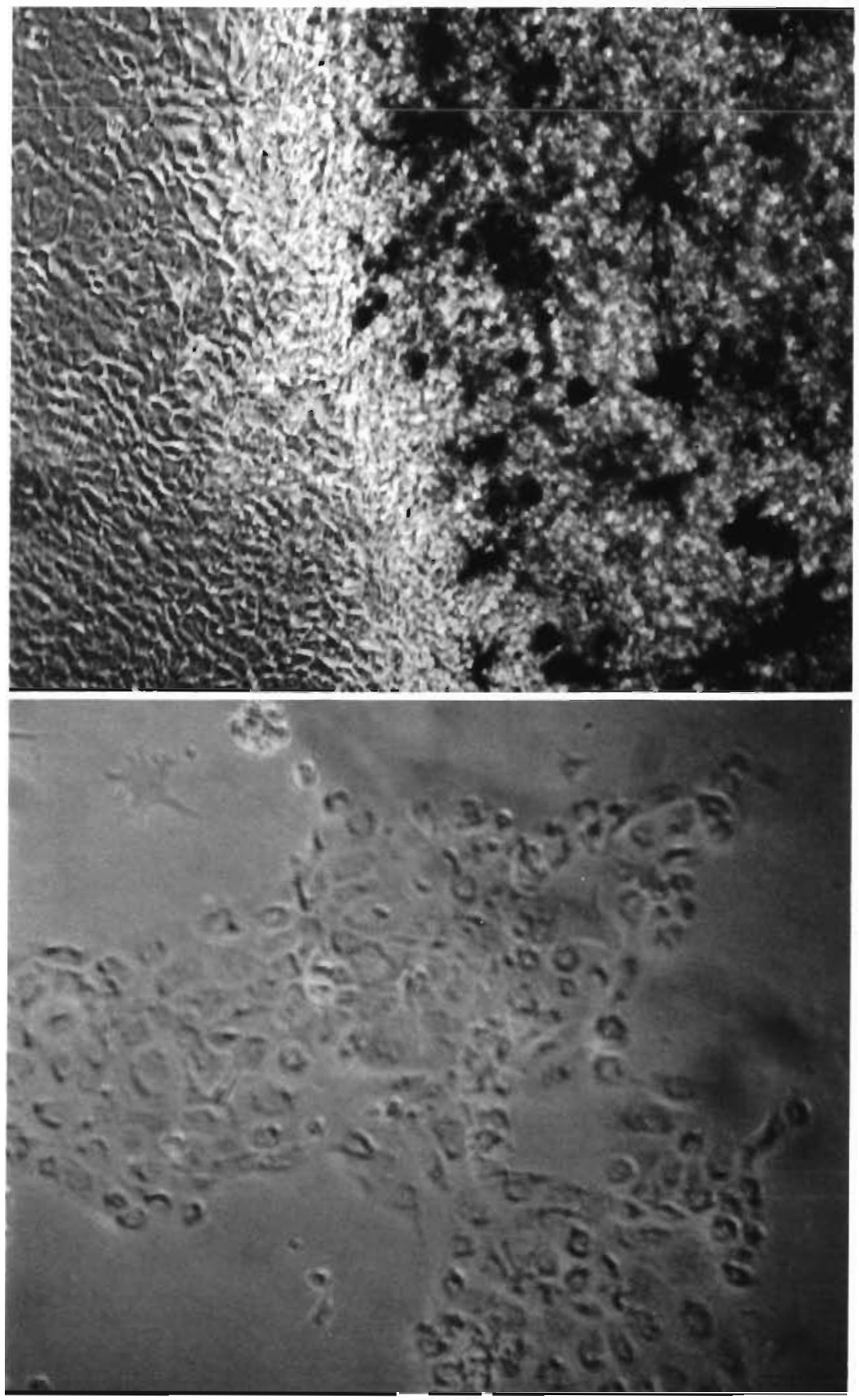

Fig. 1. Oncorhynchus mykiss. Growth of cells from the fins (upper panel) and in small cell groups (lower panel). Fin cells were obtained from a $20 \mathrm{~cm}$ trout and cultured at $14^{\circ} \mathrm{C}$ 


\section{RESULTS}

After dissociating and plating the fin tissue, clumps of round cells and small pieces of fins were scattered throughout the surface of the flask used for culture. After a few days in culture, some fibroblast-like cells migrated out of the tissue clumps (Fig. 1) and extended over the surface of the flask until the entire surface was covered by these cells. After about 2 wk small pieces of the fins were fixed by the migrating cells to the surface of the flasks. After trypsinization, the cells of the monolayer became rounded and could be transferred to other flasks at about $1: 3$ dilution. Cells grew to confluent monolayers at $14^{\circ} \mathrm{C}$ but not at $20^{\circ} \mathrm{C}$. The presence of $0.5 \%$ trout serum in the media was required for the cells to attach and grow. Ongoing cultures have been maintained for more than 4 mo, 3 to 4 passages.

Fin cell monolayers were obtained from 10 different trout, and all trout tested were able to produce fin cell monolayers. Fin cell monolayers showed scattered
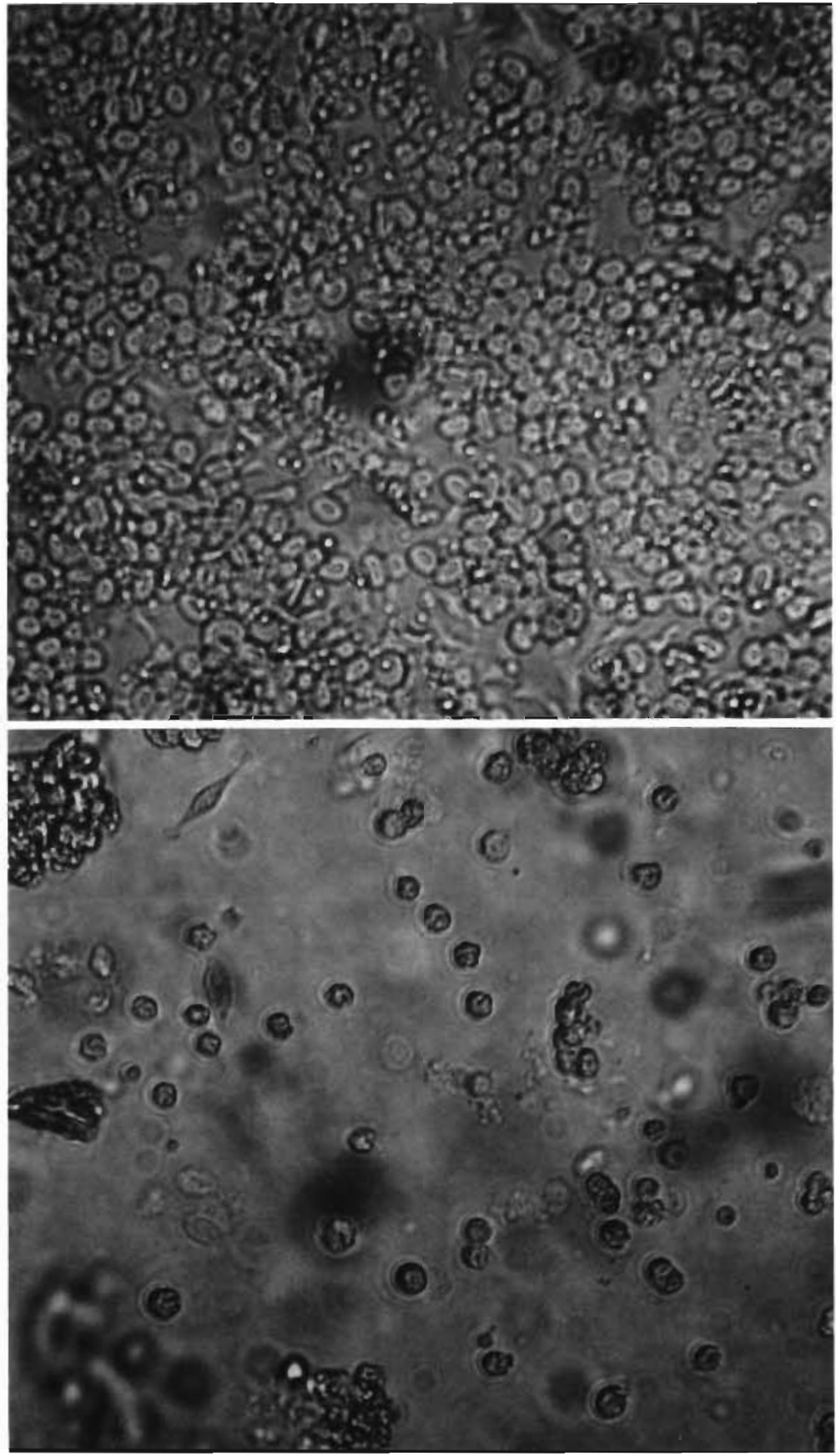

Fig. 2. Oncorhynchus mykiss. Infection of fin cell monolayers with VHSV after 3 passages with $10^{4} \mathrm{TCID}_{50}$ of VHSV $\mathrm{ml}^{-1}$ and cultured at $14^{\circ} \mathrm{C}$. Upper panel: round cells $5 \mathrm{~d}$ after infection; lower panel: cell lysis $10 \mathrm{~d}$ after infection 
positive immunofluorescence $3 \mathrm{~d}$ after infection with VHSV by using polyclonal anti-VHSV (not shown). The infected cells became rounded and finally lysed (Fig. 2 ). VHSV was released into the fin cell culture supernatants as demonstrated by more than a 1000-fold increase in the titre either by cell culture or by sandwich ELISA (Table 1).

\section{DISCUSSION}

The final goal was to investigate the in vitro trout fin cells' susceptibility to VHSV in order to use them as VHSV-antigen presenting cells for immunological studies. First, we established primary cultures by trypsinization of the fins and leaned thai fiùublatast-like cells grew out of the fin fragments to form confluent monolayers that could be propagated by subculture. We have not yet investigated either cloning or growing more than 3 to 4 passages from the original culture; however, every trout tested has been able to produce these cell monolayers $(n=10)$. The morphology of the cells has been described in Fig. 1, their in vitro susceptibility towards VHSV has been demonstrated by immunofluorescence, cell lysis, and cell culture and ELISA of their infected supernatants.

The fin cells growing in vitro should be, therefore, added to the list of trout tissues which have been demonstrated to support VHSV replication in vivo (Yasutake \& Rasmussen 1968, Chilmonczyk 1980, Chilmonczyk \& Monge 1980, Neukirch 1984, Neukirch \& Glass 1984, Chilmonczyk \& Oui 1988) or in vitro (Estepa \& Coll 1991a, b, Estepa et al. 1992). Whether, kidney leucocytes (Estepa et al. 1991), isolated kidney macrophages (Estepa et al. 1992) or haematopoietic kidney stromal cell cultures (Diago et al. unpubl.) were infected with VHSV, virus yields were similar $(6.4,2.5$ and $2.5 \times 10^{3} \mathrm{TCID}_{50} \mathrm{mI}^{-1} 200000 \mathrm{cells}^{-1}$ respectively). Virus yields of $10^{7}$ to $10^{8} \mathrm{TCID}_{50} \mathrm{ml}^{-1} 200000$ cells $^{-1}$

Table 1. Replication of VHSV in rainbow trout fin cell confluent monolayers. After 3 passages fin cell confluent monolayers (about $10^{6}$ cells per $25 \mathrm{ml}$ flask) were incubated for $1 \mathrm{wk}$ at $14^{\circ} \mathrm{C}$ in the presence or the absence of VHSV. Virus was added before the incubation or after the incubation (about 2 $\mathrm{TCID}_{50}$ per 100 fin cells). Results are expressed as TCID $50 \mathrm{ml}^{-1}$ after titration of VHSV on EPC monolayers or on ELISA.

\begin{tabular}{|llc|}
\hline Method & $\begin{array}{l}\text { Time of virus } \\
\text { addition }\end{array}$ & $\begin{array}{c}\text { VHSV } \\
\left(\mathrm{TCID}_{50} \times 10^{-3} \mathrm{ml}^{-1}\right)\end{array}$ \\
\hline EPC monolayers & $\begin{array}{l}\text { After incubation } \\
\text { Before incubation }\end{array}$ & $\leq 20$ \\
Sandwich ELISA & $\begin{array}{l}\text { After incubation } \\
\text { Before incubation }\end{array}$ & 12500 \\
& 16000 \\
\hline
\end{tabular}

were, however, obtained by using either RTG-2 or EPC cell line cultures (Basurco 1990).

The gills seem to be one of the sites of early penetration of the virus to the trout (Chilmonczyk 1980, Chilmonczyk \& Monge 1980, Neukirch 1984); furthermore they offer a great surface and an obligated site of water circulation. However, other early penetration targets could be also some of the fibroplast-like cells of the skin of the fins. In that respect, the fins too, offer a great surface and although protected by mucus they are also in permanent contact with the water.

The easy establishment of fin cell cultures from individual trout and their VHSV susceptibility make possible to study the antigen presentation capacity of these cells to their autologous lymphocytes in the absence of possible histucompatibility restriction phenomena. The possibility of keeping the trout alive while propagating their fin cell culture can be also used to make the donor trout resistant to VHSV, to allow studies on anamnesic immunological responses without possible histocompatibility restriction. In those studies the fin cell cultures might be used as VHSV-antigen presenting cells towards educated lymphocytes obtained from the same individual trout. Experiments are in progress to study this and related topics (Estepa et al. 1991, Estepa \& Coll 1992).

Acknowledgements. We appreciated the technical assistance of P. Parrilla and of $\mathrm{J}$. Coll Perez in typing. This work was supported by Research Grant AGF92-0059 from the Comision Interministerial de Ciencia y Tecnologia (CICYT), Spain. E.A. was recipient of a predoctoral fellowship of INIA

\section{LITERATURE CITED}

Basurco, B. (1990). Estudio, identificación y caracterización del virus de la septicemia hemorrágica vírica en España. Ph.D. thesis, Universidad Complutense de Madrid

Basurco, B., Coll, J. M. (1989). Spanish isolates and reference strains of viral haemorrhagic septicaemia virus show similar protein size patterns. Bull. Eur. Ass. Fish Pathol. 9: 92-95

Chilmonczyk, S. (1980). Some aspects of trout gill structure in relation to Eqtved virus infection and defence mechanisms. In: Ahne, W. (ed.) Fish diseases 3rd COPRAQ session. Springer Verlag, Berlin, p. 18-22

Chilmonczyk, S., Monge, D. (1980). Rainbow trout gill pillar cells: demonstration of inert particle phagocytosis and involvement in viral infection. J. reticuloendothel. Soc. 28: $327-332$

Chilmonczyk, S., Oui, E. (1988). The effects of gamma irradiation on the lymphoid organs of rainbow trout and subsequent susceptibility to fish pathogens. Vet. Immunol. Immunopathol. 18: 173-180

Estepa, A., Coll, J. M. (1991a). Infection of trout kidney cells with infectious pancreatic necrosis and viral haemorrhagic septicaemia viruses. Bull Eur. Ass. Fish Pathol. 11. 101-104

Estepa, A., Coll, J. M. (1991b). Infection of mitogen stimulated colonies from trout kidney cell cultures with salmonid viruses. J. Fish Dis. 14: 555-562

Estepa, A., Coll, J. M. (1992). In vitro immunostimulants for 
optimal responses of kidney leucocytes from trout surviving viral haemorrhagic septicemia virus disease. J. Fish Shellfish Immunol. 2: 53-68

Estepa, A., Basurco, B. Sanz, F., Coll, J. M. (1991). Stimulation of adherent cells by the addition of purified proteins of viral haemorrhagic septicaemia virus to trout kidney cell cultures. Viral Immunol. 4, 43-52

Estepa, A., Frías, D., Coll, J. M. (1992). Susceptibility of trout kidney macrophages to viral haemorrhagic septicaemia virus. Viral. Immunol. (in press)

Neukirch, M. (1984). An experimental study of the entry and multiplication of viral haemorrhagic septicaemia virus in rainbow trout (Salmo gairdneri, Rich.) after water-borne infection. J. Fish Dis. 7: 231-234

Responsible Subject Editor: D. E. Hinton, Davis, California, USA
Neukirch, M., Glass, B. (1984). Some aspects of virus shedding by rainbow trout (Salmo gairdneri, Rich.) after water-borne infection with viral haemorrhagic septicaemia (VHS) virus. Zbl. Bakt. ParasitKde 257: 433-438

Sanz, F., Coll, J. M. (1992). Detection of hemorrhagic septicaemia virus of salmonid fishes by use of an enzyme linked immunosorbent assay containing 2 non-competitive monoclonal antibodies against early viral nucleoproteins and high sodium chloride concentration. Am. J. vet. Res. 53: $897-903$

Yasutake, W T., Rasmussen, C. J. (1968). Histopathogenesis of experimentally induced viral haemorrhagic septicaemia in fingerling rainbow trout (Salmo gairdner). Bull. off. Int Epiz. 69: 977-984

Manuscript first received: May 15, 1992

Revised version accepted: September 23,1992 